\title{
Molecular screening of hybrid rice parental lines for bacterial blight resistance genes
}

\author{
RAMANJEET SINGH BRAR*, RANVIR SINGH GILL, JAGJEET SINGH LORE and RENU KHANNA \\ Department of Plant Breeding and Genetics, Punjab Agricultural University, Ludhiana 141 004, Punjab, India
}

Received: 18 February 2017/ Accepted: 1 June 2017/ Published online: 24 July 2017

(C) Indian Phytopathological Society 2017

\begin{abstract}
A set of twenty-nine parental lines of hybrid rice of five CMS lines and twenty-four newly identified elite restorers showing field resistance towards bacterial blight (BB) under artificial inoculation conditions were selected for molecular characterization to detect the presence of anticipated known BB resistance genes. Gene specific primers were used to detect the presence of Xa4, $x a 13$ and Xa21 genes. Nineteen restorer and four CMS lines confirmed the presence of Xa4 gene in homozygous condition exhibiting a resistant band of $150 \mathrm{bp}$. For xa13 gene only twelve restorer lines could show the presence of the gene in homozygous condition exhibiting a resistant band size of $500 \mathrm{bp}$ while none of the CMS lines showed the presence of this gene. Thirteen restorer lines and two CMS lines showed the presence of Xa21 gene in homozygous condition with the presence of single band of $1000 \mathrm{bp}$. A total of five restorer lines were identified which had all the BB resistance genes and only two CMS lines showed the presence of two BB resistance genes (Xa4 + Xa21). The comparison of disease reaction of different restorer and CMS lines against all the ten pathotypes of bacterial blight pathogen prevalent in Punjab state indicated that gene combinations Xa4 + xa13 + Xa21, Xa4 + Xa13 or xa13 + Xa21 were effective in providing resistance against all Xoo pathotypes. The lines which carried these genes individually had variable reaction against different pathotypes.
\end{abstract}

Keywords: CMS line, bacterial blight, homozygous

Global rice demand is estimated to rise from 676 million tons in 2010 to 763 million tons in 2020 and to further increase to 852 million tons in 2035. This is an overall increase of $26 \%$ or 176 million tons in the next 25 years. Further, the area planted under rice in major rice producing countries has been decreasing because of conversion of land for housing, industries and highways (Khush, 2013). Also, the world's capacity to sustain favorable food production-population balance has come under the spotlight in view of the drastic slowdown in growth of cereal production. Rice yield growth has fallen from $2.3 \%$ per year during $1970-1990$ to $1.5 \%$ during 1990 s and to $<1.0 \%$ during the first decade of the present century (Khush, 2013).

Hybrid rice is being viewed as one of the practically feasible and readily adoptable technologies to address the concerns raised above. The technology has been found to have potential to yield 15 to $35 \%$ more than the best-inbred variety grown in similar condition besides having other added advantages like reduced water usage, reduced crop protection chemical usage and more hardiness in adverse growing conditions.

To realize the actual potential of hybrid rice technology, the development of hybrids possessing resistance/tolerance to major biotic and abiotic stresses is also very vital. Many biotic and abiotic stresses are

${ }^{*}$ Corresponding author: rbramanbrar@gmail.com posing a threat to the stable production of rice hybrids and pure line varieties. Among the diseases, Bacterial blight (BB) caused by Xanthomonas oryzae pv. oryzae $(X O O)$ is one of the most destructive diseases of rice. BB is endemic in Asia as well as in some parts of West Africa. It is prevalent in both tropical and temperate areas and has also been reported in Australia, and Latin America In tropical countries BB is even more destructive. Reports from the Philippines, Indonesia and India estimate that yield loss due to the kresek syndrome of BB, which affects recently transplanted seedlings, have reached from 60$75 \%$, depending on weather, location and variety of rice (Ali et al., 2016).

Chemical control of BB in the tropical monsoon climate of Asia is impractical and no truly effective bactericide is commercially available for its control. Breeding for BB resistance has been reported as the only effective, economical and eco-friendly strategy for the management of this disease. Moreover, studies have indicated that single genes may not be effective in controlling pathogen populations of a particular area (Hunjan et al., 2014). The characterization of hybrid rice parental lines for the presence of bacterial blight resistance gene(s) is very crucial for developing hybrids with durable resistance and planning strategies for further improvement of parental lines via gene pyramiding. Modern molecular techniques have provided new tools for carrying out the genetical investigations more 
precisely. In the present studies, a set of hybrid rice parental lines were characterized for the presence of known bacterial blight resistant genes using molecular markers.

\section{MATERIAL AND METHODS}

\section{Plant material}

The plant material comprised of a set of twenty-four restorer and five CMS lines. The selected genotypes represented a resistant set identified from the screening of twenty-seven restorers and twenty-five CMS lines which were evaluated against all the ten pathotypes of bacterial blight pathogen prevalent in the Punjab state under artificial inoculation conditions (Brar, 2014). Also, the selected set represents a set of locally adapted CMS lines developed at Punjab Agricultural University (PAU), Ludhiana for use in hybrid rice breeding program and a set of elite lines identified as new restorers from the rice germplasm available at PAU. For the screening purpose inoculums of each bacterial isolate was prepared by adjusting the concentration at about $1 \times 10^{9} \mathrm{cfu} / \mathrm{ml}$. Ten fully expanded leaves of five plants in each row were clip inoculated with individual isolates forty days after transplanting. The disease severity was recorded 14 days after inoculation on the visual score basis following Standard Evaluation System (SES) of IRRI (Anonymous, 1996).

\section{Extraction of DNA}

DNA from young leaves of selected plants was isolated following a CTAB based DNA extraction method as follows (Murray and Thomson, 1980). Quantification of nucleic acids was performed by using NanoDrop ${ }^{\text {TM }} 1000$ spectrophotometer (ThermoScientific, Wilmington, USA) and the quality of DNA was checked by agarose gel electrophoresis. Finally, the concentration of DNA was adjusted to make the working concentration of $30 \mathrm{ng} / \mathrm{il}$.

\section{PCR amplification}

In vitro amplification using Polymerase Chain Reaction (PCR) was performed in an Eppendorf master cycler for confirmation of $X a 4, x a 13$ and $X a 21$, genes. PCR profile is given in Table 1. Standard lines with known genes were used as checks. PCR analysis was carried out using Xa4, xa13 and Xa21gene-linked/ specific primers as given in Table 2.

\section{Visualization of PCR amplified product}

The amplified product was visualized by electrophoresis on 1.5 percent agarose gel. For scoring of test material, the test entries carrying the resistant band of appropriate size were classified as positive for the particular gene while the lines showing the susceptible band were classified as negative for that particular gene.

\section{RESULTS AND DISCUSSION}

The CMS and restorer lines showing resistant/moderately resistant reaction to one or more Xoo pathotypes during artificial inoculations under field conditions were used to characterize for the known bacterial blight resistance genes Xa4, xa13 and Xa21. These BB resistant genes were expected to be present either in combination or

Table 1. PCR profile for gene specific primers Mp4, xa13 promoter and pTA248

\begin{tabular}{llcccc}
\hline Step no. & Cycling conditions & Temperature & Xa4 (Mp4) & xa13 (xa13 promoter) & Xa21 (pTA248) \\
\hline I & Initial Denaturation & $94^{\circ} \mathrm{C}$ & $4 \mathrm{~min}$ & $4 \mathrm{~min}$ & $4 \mathrm{~min}$ \\
II & Denaturation & $94^{\circ} \mathrm{C}$ & $1 \mathrm{~min}$ & $1 \mathrm{~min}$ & $30 \mathrm{sec}$ \\
III & Annealing & $55^{\circ} \mathrm{C}$ & $1 \mathrm{~min}$ & $1 \mathrm{~min}$ & $30 \mathrm{sec}$ \\
IV & Extension & $72^{\circ} \mathrm{C}$ & $2 \mathrm{~min}$ & $1 \mathrm{~min}$ & $30 \mathrm{~min}$ \\
V & Go to step II & & $30 \mathrm{cycles}$ & $75 \mathrm{cycles}$ & $7 \mathrm{~min}$ \\
VI & Final extension & $72^{\circ} \mathrm{C}$ & $7 \mathrm{~min}$ & $7 \mathrm{~min}$ & \\
VII & Store & $4 \stackrel{\circ}{ }$ & & & \\
\hline
\end{tabular}

Table 2. Chromosome location and primer sequence of gene specific markers for $X a 4, x a 13$ and $X a 21$ genes

\begin{tabular}{ccclccc}
\hline $\begin{array}{c}\text { Gene } \\
\text { (trait) }\end{array}$ & $\begin{array}{c}\text { Chromo- } \\
\text { some } \\
\text { Location }\end{array}$ & Marker & Primer pair & $\begin{array}{c}\text { Resistant } \\
\text { band size } \\
\text { (base pairs) }\end{array}$ & $\begin{array}{c}\text { Susceptible } \\
\text { band size } \\
\text { (base pairs) }\end{array}$ \\
\hline Xa4 & 11 & Mp4 & $\begin{array}{l}\text { F:5'-ATCGATCGATCTTCACGAGG-3' } \\
\text { R:5'-dTGCTATAAAGGCATTCGGG-3' }\end{array}$ & 150 & 450 & Wang et al. (2001) \\
xa13 & 8 & $\begin{array}{c}\text { xa13 } \\
\text { promoter }\end{array}$ & $\begin{array}{l}\text { F:5'-GGCCATGGCTCAGTGTTTAT-3' } \\
\text { R:5'-CAGCTCCAGCTCTCCAAATG-3' }\end{array}$ & 500 & 250 & Sundaram et al. (2008) \\
Xa21 & 11 & pTA248 & $\begin{array}{l}\text { F:5'AGACGCGGAAGGGTGGTTCCCGGA-3' } \\
\text { R:5'AGACGCGGTATCGAAGATGAAA-3' }\end{array}$ & 1000 & 650 & Huang et al. (1997) \\
\hline
\end{tabular}


present individually and were characterized with the help of gene specific markers.

Based on the banding pattern of the CMS and restorer lines it was observed that in case of $\mathrm{Xa4} \mathrm{BB}$ resistant gene, nineteen restorers confirmed the presence of $\mathrm{Xa} 4$ gene in homozygous condition (Table 3). Four CMS lines (PMS16A, PMS17A, PMS22A, PMS24A) also exhibited a resistant band of $150 \mathrm{bp}$, thereby confirming the presence of $\mathrm{Xa} 4$ gene in homozygous condition.

In case of xa13 gene, only twelve restorer lines could show the presence of gene in homozygous condition exhibiting a resistant band size of 500bp while none of the CMS lines showed the presence of this gene. For Xa21 gene only thirteen restorer lines showed the presence of Xa21 gene in homozygous condition with the presence of single band of $1000 \mathrm{bp}$ as shown in Table 3.

A total of five restorer lines PAU 2769-202-3-3-2-12-M, PAU 3832-79-4-1-2-3-3, PAU3842-59-7-1-1, PAU 3161-170-1-1, PAU 3832-44-5-2-1-1 were identified which had all the three ( $X a 4, x a 13$ and $X a 21) \mathrm{BB}$ resistance genes. Twelve restorers lines showed the presence of two BB resistance genes (Xa4 + xa13 or $X a 4+X a 21$ or $X a 21+x a 13)$ and six restorers lines showed the presence of single BB resistance gene ( $X a 4$ or xa13 or Xa21). Among the five examined CMS lines characterized for the presence of bacterial blight resistance genes only two CMS lines (PMS16A and PMS17A) showed the presence of two BB resistance genes (Xa4 + Xa21) as shown in Table 3. The other two CMS lines, PMS 22A and PMS 24A were found to carry Xa4 gene only. CMS line PMS 32A was found to show moderately resistant reaction against $\mathrm{PbXo}-1 \mathrm{PbXo}-4$ and $\mathrm{PbXo}-8$ isolates of bacterial blight pathogen, but based on molecular marker studies it could not show amplification patterns for any of the genes for which the material was characterized. Some other known or unknown genes or the genetic background could be playing a role or it could be the result of some erroneous observations or natural escape during field evaluations. These types of results also prove the utility of molecular markers for authentication of results based on field observations.

The comparison of disease reaction of different restorer and CMS lines against all the pathotypes of bacterial blight pathogen which carried BB resistance genes in combination or individually is presented in Table 4. The results indicated that gene combinations $\mathrm{Xa4}+$ $x a 13+X a 21, X a 4+x a 13$ or $x a 13+X a 21$ were effective in providing resistance against all ten $X o o$ pathotypes of bacterial blight prevalent in Punjab state at present. The lines which carried these genes individually had variable reaction showing moderate resistance or susceptibility against different pathotypes of bacterial blight.

The observations on disease reaction of test entries carrying different $\mathrm{BB}$ resistance genes in combinations or individually are in accordance with the literature reports (Lore et al., 2011; Singh et al., 2001).
Table 3. Amplification of genotypes with BB resistance gene specific markers

\begin{tabular}{|c|c|c|c|}
\hline \multirow[t]{2}{*}{ Restorer lines } & \multicolumn{3}{|c|}{ Target genes } \\
\hline & $\begin{array}{c}\text { Xa4 } \\
\text { (150bp) }\end{array}$ & $\begin{array}{c}\text { xa13 } \\
\text { (500bp) }\end{array}$ & $\begin{array}{c}\text { Xa21 } \\
\text { (1000bp) }\end{array}$ \\
\hline PAU 3832-44-6-3-3-2 & + & - & - \\
\hline PAU 3832-44-5-2-1-1 & + & + & + \\
\hline PAU 3832-77-4-1-2-3-3 & - & - & + \\
\hline PAU 3935-36-6-3-3-4 & - & - & - \\
\hline PAU 3842-47-5-3-2-1 & + & - & + \\
\hline PAU 3842-52-1-2-1-1 & + & - & + \\
\hline PAU3842-47-5-3-3-1 & - & - & - \\
\hline PAU 3110-37-1-1-1 & + & + & - \\
\hline PAU 2769-202-3-3-2-1-2-M & + & + & + \\
\hline PAU 3832-79-4-1-2-3-3 & + & + & + \\
\hline PAU 3075-3-38 & + & - & + \\
\hline PAU3842-59-7-1-1 & + & + & + \\
\hline PAU 3842-55-7-1-1 & + & + & - \\
\hline HRK 93-3 & + & - & - \\
\hline MT 16 & + & - & - \\
\hline IR68427-8-3-3-2R & + & + & - \\
\hline IR71033-62-15 & + & + & - \\
\hline IR72967-12-2-3 & + & + & - \\
\hline PAU 3105-45-3-1-1 & - & + & - \\
\hline PAU 3161-170-1-1 & + & + & + \\
\hline PAU 3053-31-31-1 & + & - & + \\
\hline PAU 2962-89-1-3-1 & - & + & + \\
\hline 2K6-ctk-2871-30 & + & - & + \\
\hline PAU 3750-5-1-1-2-1-3 & + & - & + \\
\hline PMS16A & + & - & + \\
\hline PMS17A & + & - & + \\
\hline PMS22A & + & - & - \\
\hline PMS24A & + & - & - \\
\hline PMS32A & - & - & - \\
\hline
\end{tabular}

$+=$ Presence of $\mathrm{R}$ gene, - = Absence of $\mathrm{R}$ gene

The information provided in the present studies is vital and unique. It can be concluded from the study that in order to develop durable hybrids giving long-term stable performance, the incorporation of bacterial blight resistance into parental lines is very crucial as this is one of the most serious threats to rice production in the Punjab as well as many other states of Indo-Gangetic plains. As no single gene is effective against all the ten pathotypes of bacterial blight pathogen prevalent in the Punjab state, the pyramiding of multiple genes could only be a viable strategy. Molecular markers have been efficiently used for the stacking of multiple BB resistance genes into desired backgrounds which otherwise is a difficult task to achieve relying on conventional approaches (Huang et al., 1997). Huang et al. (2012) have reported the marker-assisted introgression of four bacterial blight (BB) resistance genes Xa7, Xa21, Xa22 and $\mathrm{Xa23}$ into an elite hybrid rice restorer line Huahui 1035. Guvvala et al. (2013) have also reported the 
Table 4. Comparison of disease reaction of restorer and CMS lines carrying BB resistance genes against Xoo pathotypes of bacterial blight

\begin{tabular}{|c|c|c|c|c|c|c|c|c|c|c|c|}
\hline Restorer lines & $\begin{array}{c}\text { Xa } \\
\text { gene (s) }\end{array}$ & $\mathrm{PbXo-1}$ & $\mathrm{PbXo-2}$ & $\mathrm{PbXo-3}$ & $\mathrm{PbXo-4}$ & $\mathrm{PbXo-5}$ & $\mathrm{PbXo-6}$ & $\mathrm{PbXo-7}$ & $\mathrm{PbXo-8}$ & $\mathrm{PbXo-9}$ & $\mathrm{PbXo-10}$ \\
\hline PAU 3832-44-6-3-3-2 & Xa4 & MS & $\mathrm{R}$ & MR & MS & $S$ & $S$ & MS & $\mathrm{R}$ & $S$ & $S$ \\
\hline PAU 3832-44-5-2-1-1 & $\begin{array}{c}X a 4+x a 13 \\
+X a 21\end{array}$ & $\mathrm{R}$ & $\mathrm{R}$ & $\mathrm{R}$ & MR & $\mathrm{R}$ & $\mathrm{R}$ & $\mathrm{R}$ & $\mathrm{R}$ & $\mathrm{R}$ & $\mathrm{R}$ \\
\hline PAU 3832-77-4-1-2-3-3 & Xa21 & MR & $\mathrm{R}$ & MS & $\mathrm{S}$ & MR & MR & MR & $S$ & $S$ & MR \\
\hline PAU 3842-47-5-3-2-1 & $X a 4+X a 21$ & $\mathrm{R}$ & $\mathrm{R}$ & $\mathrm{R}$ & $\mathrm{R}$ & $\mathrm{R}$ & $\mathrm{R}$ & $\mathrm{R}$ & $\mathrm{R}$ & $\mathrm{R}$ & $\mathrm{R}$ \\
\hline PAU 3842-52-1-2-1-1 & $X a 4+X a 21$ & $\mathrm{R}$ & $\mathrm{R}$ & $\mathrm{R}$ & $\mathrm{R}$ & $\mathrm{R}$ & $\mathrm{R}$ & $\mathrm{R}$ & $\mathrm{R}$ & $\mathrm{R}$ & $\mathrm{R}$ \\
\hline $\begin{array}{l}\text { PAU 3832-79-4-1-2-3-3 } \\
\text { (RYT } 3217\end{array}$ & $\begin{array}{c}X a 4+x a 13 \\
+X a 21\end{array}$ & $\mathrm{R}$ & $\mathrm{R}$ & $\mathrm{R}$ & $\mathrm{R}$ & $\mathrm{R}$ & $\mathrm{R}$ & $\mathrm{R}$ & $\mathrm{R}$ & $\mathrm{R}$ & $\mathrm{R}$ \\
\hline $\begin{array}{l}\text { PAU2769-202-3-3-2- } \\
\text { 1-2-M }\end{array}$ & $\begin{array}{c}X a 4+x a 13 \\
+X a 21\end{array}$ & $\mathrm{R}$ & $\mathrm{R}$ & $\mathrm{R}$ & $\mathrm{R}$ & $\mathrm{R}$ & $\mathrm{R}$ & $\mathrm{R}$ & $\mathrm{R}$ & $\mathrm{R}$ & $\mathrm{R}$ \\
\hline $\begin{array}{l}\text { PAU 3842-59-7-1-1 } \\
\text { (RYT3238) }\end{array}$ & $\begin{array}{l}X a 4+x a 13 \\
+X a 21\end{array}$ & $\mathrm{R}$ & $\mathrm{R}$ & $\mathrm{R}$ & $\mathrm{R}$ & $\mathrm{R}$ & $\mathrm{R}$ & $\mathrm{R}$ & $\mathrm{R}$ & $\mathrm{R}$ & $\mathrm{R}$ \\
\hline HRK 93-3 & Xa4 & MS & $\mathrm{R}$ & MR & MS & $S$ & $S$ & MS & $\mathrm{R}$ & $S$ & $S$ \\
\hline MT 16 & Xa4 & MS & $\mathrm{R}$ & MR & MS & $S$ & $S$ & MS & $\mathrm{R}$ & $\mathrm{S}$ & $\mathrm{s}$ \\
\hline PAU 3842-55-7-1-1 & $X a 4+x a 13$ & $\mathrm{R}$ & $\mathrm{R}$ & $\mathrm{R}$ & $\mathrm{R}$ & $\mathrm{R}$ & $\mathrm{R}$ & $\mathrm{R}$ & $\mathrm{R}$ & $\mathrm{R}$ & $\mathrm{R}$ \\
\hline PAU 3110-37-1-1-1 & $X a 4+x a 13$ & $\mathrm{R}$ & $\mathrm{R}$ & $\mathrm{R}$ & $\mathrm{R}$ & $\mathrm{R}$ & $\mathrm{R}$ & $\mathrm{R}$ & $\mathrm{R}$ & $\mathrm{R}$ & $\mathrm{R}$ \\
\hline IR68427-8-3-3-2R & $X a 4+x a 13$ & $\mathrm{R}$ & $\mathrm{R}$ & $\mathrm{R}$ & $\mathrm{R}$ & $\mathrm{R}$ & $\mathrm{R}$ & $\mathrm{R}$ & $\mathrm{R}$ & $\mathrm{R}$ & $\mathrm{R}$ \\
\hline IR71033-62-15 & $X a 4+x a 13$ & $\mathrm{R}$ & $\mathrm{R}$ & $\mathrm{R}$ & $\mathrm{R}$ & $\mathrm{R}$ & $\mathrm{R}$ & $\mathrm{R}$ & $\mathrm{R}$ & $\mathrm{R}$ & $\mathrm{R}$ \\
\hline IR72967-12-2-3 & $X a 4+x a 13$ & $\mathrm{R}$ & $\mathrm{R}$ & $\mathrm{R}$ & $\mathrm{R}$ & $\mathrm{R}$ & $\mathrm{R}$ & $\mathrm{R}$ & $\mathrm{R}$ & $\mathrm{R}$ & $\mathrm{R}$ \\
\hline PAU 3105-45-3-1-1 & xa13 & $\mathrm{R}$ & $\mathrm{R}$ & $\mathrm{R}$ & $\mathrm{R}$ & $\mathrm{R}$ & $\mathrm{R}$ & $\mathrm{R}$ & $\mathrm{S}$ & $\mathrm{R}$ & $\mathrm{R}$ \\
\hline PAU 3161-170-1-1 & $\begin{array}{c}X a 4+x a 13 \\
+X a 21\end{array}$ & $\mathrm{R}$ & $\mathrm{R}$ & $\mathrm{R}$ & $\mathrm{R}$ & $\mathrm{R}$ & $\mathrm{R}$ & $\mathrm{R}$ & $\mathrm{R}$ & $\mathrm{R}$ & $\mathrm{R}$ \\
\hline PAU 3053-31-31-1 & $X a 4+X a 21$ & $\mathrm{R}$ & $\mathrm{R}$ & $\mathrm{R}$ & MS & MR & $\mathrm{R}$ & MR & $\mathrm{R}$ & $\mathrm{R}$ & $\mathrm{R}$ \\
\hline PAU 2962-89-1-3-1 & $x a 13+X a 21$ & $\mathrm{R}$ & $\mathrm{R}$ & $\mathrm{R}$ & $\mathrm{R}$ & $\mathrm{R}$ & $\mathrm{R}$ & $\mathrm{R}$ & $\mathrm{R}$ & $\mathrm{R}$ & $\mathrm{R}$ \\
\hline $\begin{array}{l}\text { 2k6-ctk-2871-30 } \\
\text { (Ctk-1699) }\end{array}$ & $X a 4+X a 21$ & $\mathrm{R}$ & $\mathrm{R}$ & $\mathrm{R}$ & MS & MR & $\mathrm{R}$ & MR & $\mathrm{R}$ & $\mathrm{R}$ & $\mathrm{R}$ \\
\hline PAU 3750-5-1-1-2-1-3 & $X a 4+X a 21$ & $\mathrm{R}$ & $\mathrm{R}$ & $\mathrm{R}$ & MS & MR & $\mathrm{R}$ & MR & $\mathrm{R}$ & $\mathrm{R}$ & $\mathrm{R}$ \\
\hline \multicolumn{12}{|l|}{ CMS lines } \\
\hline PMS16A & $X a 4+X a 21$ & $\mathrm{R}$ & $\mathrm{R}$ & $\mathrm{R}$ & MS & MR & $\mathrm{R}$ & MR & $\mathrm{R}$ & $\mathrm{R}$ & $\mathrm{R}$ \\
\hline PMS17A & $X a 4+X a 21$ & $\mathrm{R}$ & $\mathrm{R}$ & $\mathrm{R}$ & MS & MR & $\mathrm{R}$ & MR & $\mathrm{R}$ & $\mathrm{R}$ & $\mathrm{R}$ \\
\hline PMS22A & Xa4 & MS & $\mathrm{R}$ & MR & MS & $S$ & $S$ & MS & $\mathrm{R}$ & $S$ & $S$ \\
\hline PMS24A & Xa4 & MS & $\mathrm{R}$ & MR & MS & $S$ & $S$ & MS & $\mathrm{R}$ & $S$ & $S$ \\
\hline PMS 32 A & - & MR & MS & MS & MR & MS & MS & MS & MR & $S$ & $S$ \\
\hline
\end{tabular}

pyramiding of four resistance genes ( $X a 4, x a 5, x a 13$ and Xa21) into popular cultivar Mahsuri and two hybrid rice parental lines, PRR78 and KMR3. The BB resistance gene combinations $X a 4+x a 13+X a 21$ or $x a 13+X a 21$ have been found effective against all the ten pathotypes of BB pathogen prevalent in the Punjab state and most of the recently released pureline varieties by PAU, Ludhiana possesses either of these combinations.

The hybrid rice parental lines especially the CMS lines are needed to be improved by stacking multiple genes for bacterial blight resistance. Stacking of BB resistance into CMS lines can be more rewarding as the same CMS line can be used with a wide range of restorers. Though most of the recently identified restorer lines possess these gene combinations, however, as xa13 gene is recessive in nature, it could be effective only if present in both of the parental lines. Moreover, the information generated in this study will be helpful in the stacking of multiple BB resistance genes especially into CMS lines in order to provide durable resistance against the disease.

\section{REFERENCES}

Ali $\mathrm{H}$, Abbasi FM and Ahmad $\mathrm{H}$ (2016). Bacterial Blight, a serious threat to productivity of rice (Oryza Sativa L.), an overview. Int. J. Biosci. 9: 154-169.

Brar RS (2014). Field screening and molecular characterization for bacterial blight resistance gene(s) in a set of hybrid rice parental lines. M.Sc. Thesis. Punjab Agriculture University, Ludhiana.

Guvvala LD, Koradi P, Shenoy V and Marella LS (2013). Making an Indian traditional rice variety Mahsuri, bacterial blight resistant using marker-assisted selection. J. Crop Sci. Biotech 16: 111-121.

Huang B, Xu JY, Hou MS, Ali J and Mou TM (2012). Introgression of bacterial blight resistance genes Xa7, Xa21, Xa22 and 
Xa23 into hybrid rice restorer lines by molecular markerassisted selection. Euphytica 187: 449-459.

Huang N, Angeles ER, Domingo J, Magpantay G, Singh S, Zhang G, Kumaravadivel N, Bennett J and Khush GS (1997). Pyramiding of bacterial blight resistance genes in rice: Marker assisted selection using RFLP and PCR. Theor. Appl. Genet. 95: 313-320.

Hunjan MS, Singh PP and Lore JS (2014). Virulence frequencies of Xanthomonas oryzae pv. Oryzae on different sets of rice differentials under Punjab agroecological zones. J. Phytopathol. 67: 20-25.

International Rice Research Institute (IRRI) (1996). Standard Evaluation System for Rice. $4^{\text {th }}$ ed. IRRI, Manila, Philippines.

Khush GS (2013). Strategies for increasing the yield potential of cereals: case of rice as an example. Plant Breed. 132: 433-436.

Lore JS, Vikal Y, Hunjan MS, Goel RK, Bharaj TS and Raina GL (2011). Genotypic and pathotypic diversity of Xanthomonas oryzae pv. oryzae, the cause of bacterial blight of rice in Punjab State of India. J. Phytopathol. 159: 479-487.

Murray M and Thopson WF (1980). Rapid isolation of molecular weight plant DNA. Nucleic Acid Res. 8: 4321-4325.

Singh S, Sidhu JS, Huang N, Vikal Y, Li Z, Brar S, Dhaliwal HS and Khush GS (2001). Pyramiding three bacterial blight resistance genes (xa5, xa13 and Xa21) using marker assisted selection into indica cultivar PR106. Theor. Appl. Genet. 102: 1011-1015.

Sundaram RM, Vishnupriya MR, Biradar SK, Laha GS, Reddy GA, Rani NS, Sarma NP and Sonti RV (2008). Marker assisted introgression of bacterial blight resistance in Samba Mahsuri, an elite indica rice variety. Euphytica 160: 411-422.

Wang Z, Taramino G, Yang D, Liu G, Tingey SV, Miao GH and Wang GL (2001). Rice ESTs with disease-resistance gene or defense-response gene-like sequences mapped to regions containing major resistance genes or QTLs. Mol. Genet. Genomics 265: 302-310. 